\title{
Attacking the Sacred Cow. The Norwegian Challenge to the EC's Acquis Communautaire in the Enlargement Negotiations of 1970-72
}

\author{
Robin M. ALLERS
}

On 30 June 1970 the European Communities (EC) opened membership negotiations with Great Britain, Ireland, Denmark and Norway in Luxembourg. ${ }^{1}$ This act formally ended a decade of crises most of them caused by French president Charles de Gaulle's blockade of EC-enlargement. ${ }^{2}$ Building on the agreement reached at their summit meeting in The Hague in December 1969, the Six were able to meet the candidates with a common negotiating position that emphasised unity. As the acting Council president and the president of the Commission explained in their opening speeches, the EC would insist on the acceptance of the acquis communautaire in its entirety. Furthermore, the candidates would have to agree on the Community's political goals and the further development of communitarian policies was not to be delayed because of the enlargement process. Derogations from the acquis would not be allowed, only transitional arrangements which had to be the same for all parties. ${ }^{3}$

Speaking after his colleagues from the other candidate countries, the Norwegian Foreign Minister Svenn Stray managed to shake up the audience. As could have been expected from the application text and the White Paper, his government insisted on a special scheme for Norway's agriculture which de facto amounted to a permanent exemption of his country from the Common Agricultural Policy (CAP). Similar to his fellow applicants, Stray further demanded that Norway's voice should be heard in deliberations on a Common Fisheries Policy (CFP). Like his Danish colleague he asked that already existing agreements with Nordic non-members should be maintained. Contrary to the previous speakers, however, Stray did not mention the Community's political goals that had recently been revitalised at The Hague. ${ }^{4}$ Instead he

1. This article is based on research done for my $\mathrm{PhD}$ thesis published as R.M. ALLERS, Besondere Beziehungen - Deutschland, Norwegen und Europa in der Ära Brandt (1966-1974), Dietz-Verlag, Bonn, 2009. I am grateful for comments and suggestions from participants at the workshops on the history of the CAP in Paris (5/2009) and Maastricht (4/2010), and from participants at the 2010 conference of the Oslo International Contemporary History Network.

2. W. LOTH (ed.), Crises and Compromises: The European Project 1963-1969, Nomos, Baden-Baden, 2001; N.P. LUDLOW, The European Community and the Crises of the 1960s. Negotiating the Gaullist Challenge, Routledge, London, 2006.

3. Erklärungen bei der Eröffnung der Konferenz der Europäischen Gemeinschaften und der beitrittswilligen Staaten in Luxemburg am 30. Juni 1970, in: Europa Archiv, 15-16/1970, pp.D 351-D374, here D 351-D358. See also EG-KOMMISSION: Vierter Gesamtbericht über die Tätigkeit der Gemeinschaften 1970, Brüssel 1971, p.284.

4. J. VAN DER HARST, The 1969 Hague Summit: A new start for Europe?, in: Journal of European Integration History, 2(2003), pp.5-9; J. MITTAG, W. WESSELS, Die Gipfelkonferenzen von Den Haag (1969) und Paris (1972), Meilensteine für Entwicklungstrends der Europäischen Union?, in: 
spoke of the Rome Treaties as a suitable basis for cooperation in Europe and he merely acknowledged that the present situation seemed favourable to build bridges between the two Western European market formations, i.e. the EC and the European Free Trade Association (EFTA). ${ }^{5}$

The Norwegian declaration provoked reactions ranging from astonishment to annoyance. The claim to exempt Norway from the CAP clearly represented an attack on the Communitarian principles. However, it was not so much the claim for exceptions but the obvious lack of political commitment that provoked the Six. ${ }^{6}$ A Dutch diplomat was quoted stating that had a similar declaration come from the British, the Community would have not opened the negotiations in the first place. ${ }^{7}$ Few stayed as relaxed as Belgian diplomat Count Étienne Davignon who rightly observed that the declaration was mainly directed to a domestic audience. ${ }^{8}$

Later the same day, it was the Norwegians' turn to be shocked and annoyed. Despite intense lobbying from all four applicants, the Six decided to establish a Common Fisheries Policy disregarding the fact that enlargement with three of the world's largest fishing nations would change the Community's standing and identity in this sector completely. To representatives from Norway's influential fisheries sector, the planned CFP meant an unwelcome development and changed their relatively positive view of EC membership to outright hostility. To all those who were sceptical of EC-membership because they feared the loss of national sovereignty, the decision to implement the policy seemed proof that small states would have a limited influence in Community affairs. ${ }^{9}$

Together, the Norwegian statement and the following Council decision on the establishment of a CFP made for a worst possible start and placed Norway right next to Britain as the most difficult case in the upcoming negotiations. Indeed, Norway's intricate problems in the primary sector would also dominate the negotiations' final phase, even jeopardizing the successful termination of the entire enlargement process. Some of the Norwegian claims, among them the maintenance of direct subsidies for some dairy products or the permanent exclusion of foreign vessels from coastal waters challenged Community principles that were regarded as "sacred cows" among the

F. KNIPPING, M. SCHÖNWALD (eds.), Aufbruch zum Europa der Zweiten Generation. Die europäische Einigung 1969-1984, VWT Wissenschaftlicher Verlag, Trier, 2004, pp.3-27.

5. Erklärungen ..., op.cit., S.D371-374.

6. Eröffnung der EWG-Beitrittsverhandlungen, in: Neue Zürcher Zeitung, 01.07.1970.

7. Norwegian Ministry of Foreign Affairs (UD) 44.36/6.84-34, UD, Presseavdelingen, Kommentarer i utenlandsk presse til det norske åpningsinnlegget 30.06 .70 .

8. UD 44.36/6.84-34, Brussels to UD, 07.07.1970, EEC. Åpningen av utvidelsesforhandlingene. Samtale i det belgiske utenriksministerium.

9. UD 44.36/6.84-34, Brussels to UD, Norge og EEC - samtale med Mansholt. For a survey of reactions see H. ALLEN, Norway and Europe in the 1970s, Universitetsforlaget, Oslo 1979. Based mainly on official documents and journalistic contributions, Allen's work remains one of the most comprehensive accounts of the 1970-72 negotiations. 
Six. ${ }^{10}$ In the end, both sides were able to reach a compromise allowing Norway to sign the accession agreement on 22 January 1972 alongside the other applicants. Still, the agreement proved to be unacceptable to a majority of the Norwegian electorate. Following one of the most divisive campaigns in Norwegian history, the treaty of accession was rejected in a popular referendum on 25 September 1972. Why? Was the negative outcome of Norway's bid for membership predetermined, due to principled negotiation positions on both sides? Or did the negotiations leave room for a compromise that would have satisfied Norwegian farmers and fishermen and with them the general public? Every compromise, of course, would have had to take the Community principles into account.

The first round of enlargement has been at the centre of interest for integration historians for more than a decade now. Despite the fact that government and Community archives now allow for in depth study of internal and multilateral deliberations and processes, few studies have so far addressed the 1970-72 round in detail. ${ }^{11}$ Studies addressing the Norwegian case have mainly dealt with the question of national motives: Why did Norway stay apart from the first steps of integration in the 1950s, why did it follow the UK and Denmark in the 1960s and why did it become the only applicant not to ratify the accession treaty in 1972? Explanations have been sought in economic, geopolitical and domestic factors. Insisting that economic factors can best explain Norwegian choices to apply and to say no, Hans Otto Frøland suggests that the application under the Rome Treaties' article 237 TEEC was merely instrumental, i.e. a way to find out how far the Community was ready to go. When met with opposition based on Communitarian principles, a "national will" to achieve full membership was missing. ${ }^{12}$ Frøland's contribution highlights two important aspects that are necessary to understand Norway's attitude towards European integration: firstly, the government's struggle to find a balance between the export and shipping sector's interest in open markets and the need to protect the primary sector's special position; secondly the tactical moves resulting from this dilemma, often leading to a certain ambivalence in the government's communication. When suggesting that the constraints of Norway's political economy and a lack of political will doomed every attempt for membership to failure, however, Frøland seems to downplay another aspect: that a large part of the political, administrative and industrial elite went actively in for full membership and - also for political reasons - fought for entry both in the negotiations and in the referendum campaign. Moreover, through their numerous encounters with politicians and officials from the Six, Norwegian negotiators were susceptible to obtain a better understanding of EC cooperation, in some cases leading

10. Bundesarchiv (BA) B 136/8016, Aufzeichnung BMLF VII B3 und BMWFi, F/V B4, 26.11.1971, 176. Tagung des Rates der EG; TO-Punkt: Beitrittsverhandlungen; hier: Norwegische Landwirtschaft.

11. For an annotated bibliography see J. ELVERT, W. KAISER (eds.): European Union Enlargement. A Comparative History, Routledge, London, 2004. This first overall survey of EC and EU enlargement processes unfortunately does not contain a chapter on Norway.

12. H.O. FRøLAND, Choosing the Periphery: The Political Economy of Norway's Relation to European Integration 1948-1973, in: Journal of European Integration History, 1(2001), pp.77-103, here p.84. 
to a more positive view of the advantages offered by membership. To be sure, every Norwegian government had to negotiate for the maintenance of as much sovereignty in key areas as possible. Some politicians, however, adopted the point of view that in the end every solution had to be in line with Community principles and that political goodwill was needed to achieve a result embracing Norway's concerns. A detailed analysis of the negotiating process, contrasting attitudes and proposals on both sides is necessary to assess the impact of individual and collective initiatives pushing for a successful accession.

Very little research has been done so far on the EC's attitude towards the smaller applicant countries. Recent studies have suggested that some countries, most often led by Germany, "were willing to compromise on the acquis to ease conditions for British accession". ${ }^{13}$ This was also the case concerning Norway. ${ }^{14}$ On the other side, countries like France and the Netherlands, sometimes supported by the Commission, rejected any move likely to undermine the acquis. When worried about their national interests, however, as in the case of the CFP, these countries were able to show a great deal of flexibility. ${ }^{15}$

Looking at the development of negotiating positions on both sides and following the dynamics of the negotiations themselves, this article explores to what extent the Community was willing to consider a permanent exemption for the Norwegian primary sector (agriculture and fisheries), and how far the Norwegian government was able to move away from its maximum position demanding permanent exemptions from the CAP and the CFP. The first section revisits the negotiation positions and addresses the question of motives, i.e. why Norway applied for membership despite having problems agreeing on basic Community principles and why the community agreed to open negotiations despite being fully aware of Oslo's reluctant attitude towards political integration. The second section analyses the negotiations of 1970-72, asking to what extent both sides were willing to compromise. Was the Norwegian side ready to accept Community principles and how much support was gained from those voices among the Six who advocated for a softening of the communitarian principles? Summing up the results of the negotiations and taking into account the negative outcome of the ratification process, the concluding section raises the counterfactual question whether a different outcome would have been possible.

13. M. RASMUSSEN, State power and the acquis communautaire in the European Community of the early 1970s, in: J. VAN DER HARST (ed.), Beyond the Customs Union. The European Community's Quest for Deepening, Widening and Completion, 1969-1975, Bruylant, Brussels, 2007, pp.359-375, here p.366.

14. On Germany's special role as Norway's ally among the Six, see R.M. ALLERS, Besondere Beziehungen ..., op.cit.

15. M. RASMUSSEN, State power ..., op.cit., pp.369 f. 


\section{Motives and principles}

\section{The Norwegian challenge}

Most studies on Norway's case agree that the country opted for an application under article 237 TEEC forced by external pressures, i.e. Great Britain's and Denmark's decision to join. It is equally agreed that economic considerations dominated even though political and strategic motives also played a part. In any case, however, membership was only conceivable if derogations from existing Community policies were granted. Already when applying for EC membership in 1962, Norwegian politicians and officials stressed the geographically exposed, and thus special, character of their country's agriculture. ${ }^{16}$ One third of the country was situated North of the polar circle and the growing seasons were on average shorter than in continental Europe. Due to a landscape dominated by fjords and mountains - also further South - the average size of a Norwegian farm was five hectares compared to 11 hectares in the member states. ${ }^{17}$ All this made Norwegian agriculture comparatively unproductive and called for substantial support from the government. Maintaining this support through subsidies and protectionist measures was regarded as crucial because settlement throughout the entire country was regarded as necessary, both for reasons of nation building and for reasons of security, referring to the frontier with the Soviet Union. The latter arguments also called for the protection of the equally dispersed fishing industries, relying mainly on smaller vessels and operating in the coastal waters rich in fish. In 1961 Norway had unilaterally extended its fishing limits to 12 nautical miles and had defended this decision ever since. In this sector, however, Norway had developed into an exporting power of significance and the well organized marketing organisations had to balance their reluctance to allow competition with their interest in access to European and World markets. Nevertheless, both farmers and fishermen were equally sceptical about giving up the shelter provided by the government and to accept the necessary adaptation and liberalisation as a consequence of EC membership. ${ }^{18}$

The insistence on special conditions for the primary sector was even more important as scepticism towards membership was also linked to political reservations about the integration process. Norway had been absent at the creation of the supranational institutions. Pointing to its young age as an independent nation state and to the recently achieved liberation from German occupation in World War II, Norway refrained from any limitation of its sovereignty and proved to be particularly allergic to the term "union". In addition, being a country with a distinctive social democratic

16. H.O. FRØLAND, Advancing Ambiguity: On Norway's application for EEC-membership in 1962, in: S. DAHL (ed.), National Interest and the EEC/EC/EU, Trondheim, DKNVS Skrifter, 1999, pp. 53-76; K.E. ERIKSEN, H. PHARO, Kald krig og internasjonalisering 1949-1965, Norsk Utenrikspolitikks Historie (NUPH), vol.5, Universitetsforlaget, Oslo, 1997, pp.339-249.

17. F. BOUYSSOU, Les problèmes agricoles d'une Europe à dix, in: L'Europe en formation, 138-139(Sept.-Oct. 1971), pp.3-7.

18. The most thorough and comprehensive analysis of Norway's political economy and its reluctance to join the Common Market is H.O. FRØLAND, Choosing the Periphery ..., op.cit. 
profile, Norway regarded the emerging Communities as a Western European fortress, ruled by conservative governments with a capitalistic agenda.

In 1962 external pressure resulting from the British and Danish applications was the single most important reason to consider an application. Economic considerations - the prospect of seeing at least one of its main trading partners and at least one Nordic neighbour move over behind the Community's tariff walls - were decisive for Norway's decision to seek a form of association. Although some politicians and bureaucrats had become interested in the political ideas underlying the European project, the Norwegian government was quite happy with the EFTA solution and would have preferred a less committing affiliation. Little was known by then about the CAP and its possible impact on Norwegian agriculture - not to speak of the non-existent fisheries policy. But scepticism was growing among representatives from the primary sector as to Norway's ability to shape the EEC's policies in these domains. Moreover, less than 20 years after the end of World War II the idea of joining a supranational community in which Germany and France were the dominating powers had little appeal. Facing growing opposition in the electorate and among party rank and file, the governing Social Democrats were relieved rather than shocked when de Gaulle brought the process to an end. ${ }^{19}$

Norway's 1967 application was again first and foremost provoked by the renewed British initiative followed immediately by Denmark and Ireland. This time, however, it was a government composed of both sceptics and advocates that forwarded an application. ${ }^{20}$ Those who had voted against an application in 1962 now agreed to renew it, although with great difficulties. The sceptics from the centre party - among them Prime Minister Per Borten - the Christian Party and the Liberals finally gave in to pressure from their conservative coalition partners and worked out an application for full membership. The alternative preferred by the sceptics since 1962, an association agreement under article 238 TEEC, was rejected by the conservatives and even judged undemocratic by legal experts. The latter emphasised that such an agreement would not allow the associated country to exert its influence on Community decision making while forcing it to adopt most of the EC's policies. As the labour friendly daily Arbeiderbladet pointed out, Britain had rejected an association agreement exactly for this reason. ${ }^{21}$ In addition, several EC countries regarded an association

19. H.O. FRØLAND, Advancing Ambiguity ..., op.cit.; K.E. ERIKSEN, H. PHARO, op.cit.

20. H.O. FRØLAND, The Second Norwegian EEC-Application, 1967: Was There a Policy at all?, in: W. LOTH (ed.), Crises and Compromises ..., op.cit., pp.437-458; D.A. KRISTOFFERSEN, Norway's Policy towards the EEC. The European Dilemma of the Centre Right Coalition (1965-1971), in: K. RÜCKER, L. WARZOULET (eds.), Quelle(s) Europe(s)/Which Europe(s)? Nouvelles approches en histoire de l'intégration européenne, PIE Peter Lang, Bruxelles, 2006, pp. 209-224; R. TAMNES, Oljealder 1965-1995, NUPH, Vol.6, Universitetsforlaget, Oslo, 1997, pp. 165-167.

21. Assosiering til EEC uforenlig med Grunnloven? Paragraf 93 krever at vi fär medbestemmelsesrett!', in: Arbeiderbladet, 05.07.1967. Interestingly, the EEA-agreement, governing Norway's relationship with the EU since 1994, has to strive with exactly the same problem. E.O. ERIKSEN, Norges demokratiske underskudd, in: Nytt Norsk Tidskrift, 4(2008), pp.368-379. 
agreement as inadequate for an industrialised country. ${ }^{22}$ After lengthy internal debates, the government decided to send an application under Art. 237 TEEC without mentioning alternative solutions. However, the sceptics insisted that the official government White Paper preparing the negotiations refrain from declaring membership as the only option. ${ }^{23}$ Moreover, the claim for special rules had to be given a central part. According to Frøland, the government went actively in for testing to what extent the Community would be ready to meet Norway's demands. Some government members had become convinced that the Community might be willing to offer a de facto exemption from the CAP under the concept of regional policy. ${ }^{24}$ There were, however, few indications that the Six would have accepted such a deal. Already in 1967, a solid consensus existed in Brussels that every exception had to be negotiated in conformity with the principles laid down in the Treaties of Rome. According to Italian Foreign Minister Amintore Fanfani it was unimaginable - even with a good portion of goodwill - to see the Community agree to measures that were likely to destroy the edifice that the Community had so carefully constructed over years. ${ }^{25}$ Even supporters of Norwegian entry, like Willy Brandt, insisted that every solution had to be found within the framework of the Rome Treaty and proposed to look for a deal under the Community's regional policy. ${ }^{26}$ This proposal did not entirely meet Norwegian claims, however. To secure settlements along the long coastline, in the many mountainous areas and in the far North, Oslo was asking for a permanent exemption from CAP and the CFP for the entire country. ${ }^{27}$

When de Gaulle vetoed enlargement for the second time in December 1967, the question whether Norway's claims would stand any chance in negotiations with the Six was postponed for the second time. Although this outcome was greeted with relief by the sceptics, the government joined Britain, Denmark, and Ireland in maintaining its application. The following two years showed that there was no viable alternative to membership. As long as Denmark and Britain prioritized membership, neither plans for revitalizing EFTA nor plans for the creation of a Nordic customs union

22. UD 44.36/6.84-25, Notat, UD, 1. Handelspol. Kontor, 15.03.1967, Statsråd Willochs besøk i Haag 8.-9. mars 1967. Samtale med statssekretær de Block; BA, B 136, Bd.7980, Aufzeichnung BK/ Gruppe II/1, 11.08.1967, Betr.: Beitritte und Assoziationen der EWG.

23. Norwegian National Archives (Riksarkivet, RA), SMK, regj. konf., bd. 24, 13.07.1967.

24. H.O. FRØLAND, The Second Norwegian EEC-Application ..., op.cit., pp.441 and 456.

25. UD 44.36/6.84-26, Rome to UD, 03.05.1967, Samtale mellom Willoch og utenriksminister Fanfani 26.04.1967. See also UD 44.36/6.84-25, Brussels to UD, 17.10.1966, Willoch's besøk i Brüssel.

26. UD 44.36/6.84-28, Notat, UD, 1. Handelspol. Kontor, 27.06.1967, Utenriksminister Brandts besøk i Oslo; PA AA, B 60, Bd.520, Oslo to AA, 26.06.1967; PA AA, B 20, Bd.1246, Dg IA über D I an Staatssekr., 24.07.1967, Betr.: Norwegischer Antrag auf Beitritt zur EWG.

27. Norwegian diplomats emphasized the need to make their German counterparts understand that it was equally difficult to maintain effective fishing and agriculture in the North as in the fjords and valleys further South of the country. UD 44.36/6.84-29, Notat, UD, 1. Handelspol. Kontor, 12.10.1967, Møte i den norsk tyske blandede kommisjon 16.-17.10.67; EEC og utvidelsesspørsmålet. 
(NORDEK) had any future. Different schemes for accession or free trade agreements gained no support as long as they did not include a roadmap to membership. ${ }^{28}$

This situation remained unchanged when the Community finally decided to open negotiations with the applicants, following General de Gaulle's retreat from power in April 1969. As mentioned above, the same demands as in 1962 and in 1967 were key elements of Foreign Minister Stray's opening address on 30 June 1970. To his credit, the declaration he read on behalf of his government was not what Stray would have chosen to say in private. In a government split on the EC membership issue, his party, the conservatives (Høyre) were the only one unambiguously in favour. Stray himself was even known to be one of the few who supported entry for political reasons and in the run-up to the negotiations he had already clashed several times with the Prime Minister over questions of strategy. Supported by experts from the ministry of Foreign Affairs and by members of the Parliament's foreign affairs committee he maintained that in order to obtain goodwill, Norway had to show its willingness to fully participate in the European project. ${ }^{29}$ This meant both the acceptance of the Community's political goals and a conciliatory line with regard to special solutions for the primary sector. To insist on demands that would go explicitly against community principles would only harden positions. At the same time Stray knew that neither the political class nor the electorate would accept EC membership without obtaining major concessions if not a permanent exemption from the CAP. When meeting the Six for the first bilateral round of negotiations on 22 September 1970, Stray thus accepted the basic principles of the Community's position, but he reiterated the demand for a permanent exemption from the CAP together with the claim to participate in the formulation the CFP. As he explained to his EC colleagues, if no satisfying solution would be found, it was not sure whether a majority for entry could be secured in the population. ${ }^{30}$

Both sectors were closely linked but in the negotiations they were treated in separate chapters and indeed posed quite different problems: Contrary to the agrarian sector where Norway was irrelevant on an international basis, its fisheries sector was one of the largest in the world and contributed significantly to the country's export. Whereas the CAP had been part of Norwegian discussions on EC membership since 1962, neither in 1962 nor in 1967 the Community had agreed on a CFP. And finally, in the fisheries sector Norway was not alone in challenging the Community.

All four applicants had demanded participation in shaping the emerging common policy in this sector. Oslo's main argument here was that enlarging the Community by three of the world's leading exporters of fish would change the character of the CFP anyway. Distinguishing itself from the other candidates, Norway also claimed

28. See contributions by Hans Otto Frøland and Dag Axel Kristoffersen and Robin Allers in: J. HECKER-STAMPEHL (ed.), Between Nordic ideology, economic interests and political reality. New perspectives on Nordek, Finska Vetenskaps-Societeten, Helsinki 2009.

29. See for example the debates in the Norwegian parliament's committee for foreign affairs (Stortingets Utvidede Utenriks- og konstitusjonskomité, SUUKK) on the 27.08 and 08.10.1970.

30. HAEU, SGCICEE, 12109, French ministry of Foreign Affairs (MAE), Bruxelles to Paris, 24.09.1970. 
that its system of distribution and price management was more adequate than the one proposed by the Community. Most importantly, Norway demanded a special permanent regime for its entire coastline. The 12-mile exclusive zone that Norway had established in 1964 was to be preserved and further expansion not to be excluded. Consequently, Norway's negotiators were demoralised when the Community agreed on two directives aimed at establishing the CFP the very day the negotiations were opened. Although the timing was nearly provocative, the decision itself did not come unexpected. Diplomats had reported since 1966 that a CFP was in the making and that Norway probably would have to adapt to it. ${ }^{31}$ Since The Hague summit in 1969 Norwegian politicians and diplomats, together with their even more active Danish and British colleagues, had in vain tried to influence the Community. ${ }^{32}$ On 30 June the CFP was on its way and had become part of the EC's negotiation position.

At least the applicants were now aware of what the new policy would look like and could start to conceive a strategy to revise it. In Norway working groups consisting of government experts and representatives from the primary sector discussed four alternatives: The first alternative was to maintain the Norwegian policy with exclusive fishing rights reserved for Norwegian citizens inside the 12-mile zone. This was the preferred solution for both the government and the primary sector, but was regarded by officials as having little chance of acceptance by the EC. ${ }^{33}$ The second alternative was the so-called establishment or settlement strategy, proposing fishing rights in the exclusive zone to all those who would settle formally in the coastal region. Two other alternatives were discussed but rejected as unacceptable to Norway: a division of the exclusive zone into two 6-mile zones, the outer-one being accessible to vessels from countries with traditional fishing rights, and, finally, a division of the coastline, granting special rights (i.e. maintenance of the 12-mile zone) only to Northern Norway because of harsh conditions. This last alternative corresponded to the "regional" solution informally proposed by Community representatives for both the agricultural and the fisheries sector. In the Norwegian view, however, the entire country had to be regarded as a special area. A division of the coastline would not make sense, it was argued, because fishermen from the South followed the fish to the North according to the season. ${ }^{34}$

Discussions on the negotiation position uncovered considerable disagreement inside the government and among members of parliament as to how to phrase the Norwegian concerns. Most pro-European members of the cabinet, assisted by diplomats

31. UD 44.36/6.84-25, Notat, Handelsdep., Avd. for utenrikshandel, 19.11.1966, Økonomiske problemer ved en norsk tilslutning til EEC.

32. UD 44.36/6.84-31, Paris to UD, 11.12.1969, Handelsminister Willochs samtale med utenriksminister Schumann 10/12.

33. SUUKK, Session on 27.08.1970.

34. UD 44.36/6.84-41, Notat, Brüssel, 16.17.1971, Utvidelsen av EF. Fiskerigrensen og jordbruket i Norge - Sverige og EF. See also UD 44.36/6.84-36, Notat, UD, Forhandlingsdelegasjon 21.11.1970, Frankrikes syn på de norske medlemsskapsforhandlinger. In earlier negotiations a division had been discussed in governement and parliamentary consultations, but was never proposed officially. See K.E. ERIKSEN, H. PHARO, op.cit., p.367. 
from embassies in Brussels and Paris, argued that a conciliatory line would be more productive. To insist on demands that would go explicitly against Community principles would only harden positions. ${ }^{35}$ Despite these disagreements on strategy, there was a broad agreement as to the necessity of obtaining derogations.

\section{The Community's response}

The Norwegian demand for exemption from the CAP was perceived as a challenge to core Community principles. Introducing a study by Hans Otto Frøland on Norway's claims for special rights, Fernando Guirao suggested in 2001 that further research was needed to clarify why the Community opened negotiations with this country at all. ${ }^{36}$ Indeed, in the course of the negotiations it was suggested several times that Norway should rather look for an agreement similar to the one Sweden and the other remaining EFTA-members were after. At the same time, however, NATO-member Norway was always regarded as a natural candidate for membership. Willy Brandt in particular maintained that Norway and the other Scandinavian countries should take part in the European project because of their democratic traditions. ${ }^{37}$ French politicians such as Foreign Minister Maurice Schumann also expressed their interest in seeing Norway becoming a member. ${ }^{38}$ Norwegian negotiators did their best to convey the image of Norway being a European country. Meeting Community representatives, both Brussels based diplomats and members of government repeatedly insisted on the fact that Norway was applying for membership. This became particularly evident after a minority government formed by the labour party took over in March 1971. A statement to the negotiations conference and a new white book were both regarded as pro-European in tone and substance. ${ }^{39}$ Prime Minister Trygve Bratteli soon gained a reputation for being the Scandinavian statesman with the

35. A. HALLENSTVEDT, B. DYNNA, Fra skårunge til høvedsmann. Med Norges Fiskarlag gjennom 50 år, Norges fiskarlag, Trondheim, 1976, p.428.

36. F. GUIRAO, Peripheral countries and the Integration of Europe, in: Journal of European Integration History, 1(2001), p.7; cf. H.O. FRØLAND, Choosing the Periphery ..., op.cit.

37. R.M. ALLERS, Die schwierige Erweiterung. Willy Brandt und die Verhandlungen der EG mit den skandinavischen Ländern 1966-1973, in: A. WILKENS (ed.), Wir sind auf dem richtigen Weg. Willy Brandt und die europäische Einigung, Dietz, Bonn, 2010, pp.276-304.

38. Schumann told his Norwegian colleague in December 1970 that France wanted to help for two reasons: Out of a deep sympathy for heaving experienced the same situation in 1940 and because both countries shared a similar view on most questions in international affairs, especially regarding détente. UD 44.36/6.84-37, Paris to UD, 11.12.1970, Utenriksministerens samtaler med utenriksminister Schumann, 10.12.70.

39. UD 44.36/6.84-39, Notat, UD, Forhandlingsdel., 02.04.1971, Referat fra ministermøtet EF-Norge 30.03.1971; UD 44.36/6.84-39, Brussels to UD, 01.04.1971, Norge-EF. Siste Ministerrådsmøte; UD 44.36/6.84-39, Brussels to UD, 02.04.1971, Norge-EF. Erklæringen av 30.05.1971. 
strongest European attitude..$^{40}$ But even at the times of the coalition government, whose Prime Minister Borten was accused of playing a double game, negotiating for membership while publicly expressing a negative attitude towards the EC, the Ministers of Trade and Foreign Affairs would present the membership option as official policy. ${ }^{41}$ If the Norwegian application was merely instrumental, this was not the impression given to the $\mathrm{EC}$.

How then did the Six deal with the ambivalence characterising the Norwegian position and how did they react to the challenge it represented to the acquis? A permanent exemption of the entire country from CAP-rules was not acceptable to the Community. Part of the package deal at the basis of the Rome Treaties, the CAP was at the core of the acquis. ${ }^{42}$ When Norwegian politicians and diplomats first launched the idea of permanent exceptions in 1962, the Community reacted with reservations. ${ }^{43}$ However, the Norwegian case never made it further than through exploratory talks before de Gaulle brought the enlargement process to an end. Five years later, when Norway again presented its plan of joining with reservations, the EC was split between France and the so-called friendly five. German support for enlargement was then much more political, linked to the so called Ostpolitik. ${ }^{44}$ Concerning Norway's request for special rights, however, Community representatives were even more explicit in their rejection. ${ }^{45}$ The EC had just gone through the empty chair crisis that was partly provoked by a row over the CAP. Despite its bad reputation as a setback to further integration, the Luxembourg compromise of 1966 had certainly strengthened the CAP. As a result, Germany, Italy and the Benelux countries supported enlargement but did not dare to provoke France over agriculture. Following de Gaulle's second "no" in December 1967, some countries considered, but later dismissed a plan to use France's dependence on the CAP as a "weapon" in order to force a breakthrough in the enlargement question. Politicians and officials alike were prudent enough to

40. INSTITUT FÜR ZEITGESCHICHTE (ed.), Akten zur Auswärtigen Politik der Bundesrepublik Deutschland, (AAPD), 1972, Doc.19, Aufzeichnung Botschafter Sachs, 02.02.1972. Cf. HAEU, Oral history Programme, Voices on Europe, Wellenstein, INT 569, p.31.

41. UD 44.36/6.84-25, Notat, (Bonn), 22.02.1967, Willochs samtale med Brandt. Only when Foreign Minister Stray claimed in November 1970 that, contrary to 1962, Norway was now in favour of integration out of political reasons, the Prime Minister intervened. For a recent, archive based study of his, see H. BERNTSEN, Staurberaren. Per Borten, Aschehoug, Oslo 2007, pp.349 f.

42. See N.P, LUDLOW, The Green Heart of Europe: the rise and fall of the CAP as Europe's central policy, 1965-85, in: K. PATEL (ed.), Fertile Ground for Europe? The history of European integration and the Common Agricultural Policy since 1945, Nomos, Baden-Baden, 2009.

43. K.E. ERIKSEN, H. PHARO, op.cit., pp.344 f.; PA, B20, Bd.1246, Brussels to AA, 14.11.1962, EWG-Beitrittsverhandlungen mit Norwegen; 1. Ministertagung am 12.11.1962.

44. A. WILKENS, L'Europe en suspens. Willy Brandt et l'orientation de la politique européenne de l'Allemagne fédérale 1966-1969, in: W. LOTH (ed.), Crises and Compromises ..., op.cit., pp. 323-343, here p.329.

45. R.M. ALLERS, Besondere Beziehungen ..., op.cit., pp. $251 \mathrm{f}$. 
use this weapon at best indirectly or passively. ${ }^{46}$ The fear of destabilizing a carefully constructed compromise also dominated the situation on the eve of the EC summit at The Hague in December 1969. A finalization of the CAP's financial system was due until the end of the year. But instead of using France's agreement finally to go ahead with enlargement for a revision of the CAP, the German government again refrained from all kind of pressure and judged it more important to secure French President Georges Pompidou's consent to go ahead with enlargement. ${ }^{47}$ This gentlemen's agreement buried the Mansholt plan that represented everything unpopular with European integration in Norway. But it also made the Six close ranks on the existing CAP rules. ${ }^{48}$ Thus, when Norway presented its negotiation position to the Community in June 1970, the Six stood more firmly than ever behind the CAP. The defence of the acquis had now become a central part of the negotiation position. Exceptions would be granted only for a transitional period which had to be the same for every country and every sector. The unifying approach was reinforced by the decision to let the Council and the Committee of Permanent Representatives (Coreper) conduct the negotiations instead of letting every country negotiate on its own behalf. The Commission was assigned the role of a mediator. ${ }^{49}$

There was some understanding among the Six about Norway's main argument for an exemption, i.e. the relatively insignificant size of its agriculture. At the same time it was met with a powerful counter argument: the fear of setting a precedent. This point concerned both the existing Community and the potential new members. To accord one country permanent exemptions would not only undermine the basic principles of solidarity, but such a step, it was argued, would also encourage both current member states and applicants to ask for similar derivations thus undermining the CAP and further complicating the enlargement process. Norway's other argument, emphasising that special conditions asked for special rules, was rebutted as well. EC representatives instead pointed to the possibility of granting special conditions for certain regions, e.g. Northern Norway under the rules of regional policy. The moun-

46. See N.P. LUDLOW, Negotiationg the Gaullist challenge ..., op.cit., p.191; H. TÜRK, Europapolitik der Grossen Koalition, Oldenbourg, München, 2006, p.222; R.M. ALLERS, Alternatives to Membershipor temporary solutions? The German proposal for a commercial arrangement and the EEC's attitude towards NORDEK (1967-1970), in: J. HECKER-STAMPEHL (ed.), Nordic Ideology, pp. 167-187, here p.171.

47. See Carine Germond's contribution to this special issue. See also G. THIEMEYER, The Mansholt Plan, the definite financing of the Common Agricultural Policy and the enlargement of the Community, 1969-1973, in: J. VAN DER HARST (ed.), Beyond the Customs Union ..., op.cit., pp. 197-222, here pp.217 f.

48. On the Mansholt plan see Katja Seidel's contribution to this special issue.

49. N.P. LUDLOW, An Opportunity or a Threat. The European Commission and the Hague Council of December 1969, in: Journal of European Integration History, 2(2003), pp.11-25. See also PA AA, B 20, Bd.1901, Brussels to AA, 01.03.1972, Betr. Abschlußbericht über die Beitrittsverhandlungen. 
tainous regions of France and Germany and Southern Italy were mentioned as examples for regions receiving special support. ${ }^{50}$

Against this background, unlucky as it was, the timing of the CFP-initiative was far from being unintended. As enlargement Commissioner Jean-Francois Deniau explained to Norwegian diplomats, the CFP was the final piece in the construction that was the CAP. ${ }^{51}$ From the logic underpinning its French inspired strategy, the Community had to face the applicants with an established policy also in this sector. In fact, given the applicants' strength in the domain of fisheries, the Community seemed to gain a considerable advantage from a common approach. Furthermore, national interests of certain Community members also had an impact. According to the report by British chief negotiator Sir Con O'Neill, the decision to agree on a directive establishing a CFP at the 30 June session resulted from internal pressure on the French Minister who teamed up with his Dutch colleague Pierre Lardinois and was supported by the Commission. ${ }^{52}$ As mentioned above, Norwegian politicians and diplomats, together with their even more active Danish and British colleagues, had tried to influence the making of the CFP. Visiting Norway at the end of May, German Minister of Economic Affairs Karl Schiller had been asked by government representatives to intervene in Norway's favour. Schiller indeed called his colleague, Minister of Agriculture Josef Ertl who represented Germany at the Council meeting on 30 June..$^{53}$ Yet, Ertl's remark that Norway's interests as a fishing nation should be taken into consideration was met with opposition from a number of countries that had an interest in strengthening the Community position on agriculture and fisheries as well as from the Commission. The Dutch delegation feared

„,bei allem Verständnis für die deutsche Haltung große Schwierigkeiten, wenn man die Wünsche der Beitrittskandidaten schon jetzt berücksichtige. Die Gemeinschaft könne jetzt keinen ,standstill' anwenden, sondern müsse ihre Vorstellungen präzisieren. Das schließe nicht aus, daß später mit den Beitrittskandidaten hierüber gesprochen werde“" .54

The episode is a good example of the Community method at work. It also shows that German support for the applicants had a tendency to vanish once the unity among the Six and friendship with France in particular was in danger. As Guido Thiemeyer has pointed out, "Germany had to accept the French position as a precondition for enlargement and deepening the Community". ${ }^{55}$

50. 44.36/6.84-29, Referat, 1. Handelspol. kontor, 19.10.1967, Drøftingene med Mansholt; UD 44.36/6.84-25, Brussels to UD, 17.10.1966, Willochs samtale med Robert Marjolin; UD 44.36/6.84-25, Brussels to UD, 18.10.66, Willoch's besøk i Brussel.

51. UD 44.36/6.84-36, Bonn to UD, 27.10.70, EEC-utvidelsesforhandlingene.

52. C. O'NEILL, Britain's Entry into the European Community, David Hannay, London 2000, pp.251 and 253; PA AA, B 20, Bd.1833, Brussels to AA, 02.07.1970, 119. Tagung des Rates (Landwirtschaft) am 29. und 30. Juni in Luxemburg, hier: TO-Punkt 7: Gemeinsame Fischereipolitik.

53. PA AA, B 60, Bd.774, Oslo to AA, 30.06.1970, Besuch Schillers in Oslo; PA AA, B1, Bd.342, Schiller an Brandt, 11.07.1970.

54. PA AA, B 20, Bd.1833, Brussels to AA, 02.07.1970, Betr.: 119. Tagung des Rates (Landwirtschaft) 29./30.6 in Luxemburg, hier: TO-Punkt 7: Gemeinsame Fischereipolitik; cf. C. O’NEILL, op.cit., pp.254-256.

55. G. THIEMEYER, op.cit. p.219. 
When the Norwegian demands were negotiated for the first time on 22 September, the French Foreign Minister refused an initiative by the German presidency (supported by Dutch State Secretary Henri Johan de Koster), to consider the applicant's right to participate in shaping the CFP. According to Ambassador Jean-Marc Boegner,

“M. Schumann a fait valoir qu'il convenait d'écarter toute formule susceptible d'entrainer, sous une forme ou sous une autre, la participation des États candidats aux délibérations de la Communauté". ${ }^{56}$

The other members finally agreed on this position. In return Schumann proposed that the Community could acknowledge Norway's special problems in the fisheries sector, particularly with regard to the maintenance of population in certain areas. While this agreement of 22 September did not give Norway the assurance for the special treatment it had asked for, it was later referred to when a special protocol was proposed as the final compromise. The Community had thereby accepted Norway as a special case. The tactical concept agreed upon at the first bilateral meeting in September 1970 was to recognise Norway's special concerns and to postpone a solution until after the British case had been solved.

Both parties were from the outset principled in their positions but willing to find a compromise. For different reasons both inside the Norwegian government and among the Six proponents for a principled stance were challenged by others who opted for a more conciliatory line, open for compromise. In fact, as Aril Underdal has pointed out, the negotiations were primarily integrative in character, with both sides aiming for a successful conclusion. ${ }^{57}$

\section{The negotiations}

When negotiations moved beyond the fact finding phase in summer 1971, the two positions were still quite far from each other. Due to internal pressure the Norwegian government's negotiating ability was extremely limited. The centre-right government that had submitted the application had to resign in early 1971 over a disagreement on the negotiation strategy. The labour government that succeeded it was unified in its determination to continue negotiations and to meet the Community with a more positive attitude; yet it had to take the primary sector's concerns into account as well.

A broad Anti-EEC coalition ranging from conservative agricultural interest groups to the radical left had extended its campaign against entry. Following its forced resignation from government in March 1971, the Centre Party abandoned its tactical ambivalence and positioned itself unambiguously on the "No" side. This brought the

56. HAEU, SGCICEE, 12110, MAE, Boegner à Paris, 24.09.1970.

57. A. UNDERDAL, Forhandlingene om Norsk medlemskap i EF - En studie av rammebetingelser, Master thesis, University of Oslo, 1972, p.68. 
number of votes necessary to reject the accession treaty in parliament short of two. The fight about the votes in a consultative referendum therefore became even more important. The Labour government, however, though in favour of membership, hesitated to campaign actively for entry. Instead, the party leadership proposed to wait until after the terms of entry would be known, i.e. until after the end of negotiations, before they would recommend membership. This can be seen either as an honourable move of fairness or as a lack of leadership. The party elite, led by Prime Minister Trygve Bratteli who did not hide his personal preference for membership out of political reasons, decided to show consideration for his voters at the periphery and for the large group of euro-sceptics inside its ranks, particularly at the left wing and in the party's youth organisation, Arbeidernes Ungdoms Fylke (AUF). The result of this strategy was twofold: it gave the no-side a huge head start and it increased the pressure on the government to obtain a negotiation result in line with public expectations. ${ }^{58}$

In the meantime, the Heath-Pompidou summit of May 1971 had led to a breakthrough in the British negotiations. This enabled the Six to concentrate on the other candidates' demands and to consider far reaching compromises without having to fear British counter moves of a dimension that would exacerbate the entire process. On the other hand, having concluded a deal with Britain, the Six had found acceptance for their position in principle and were even less willing to compromise. Moreover, the British deal still needed to be ratified and as the Financial Times remarked "there would be an outcry from Britain fishermen if the Norwegians were to be given preferential treatment". 59

A significant turn in the Community's attitude occurred in summer 1971. Community negotiators at this point realised that Norwegian fears of not being able to ratify an agreement unanimously rejected by the interest groups were real. As intended by Norwegian negotiators the question now turned political. Following the change of presidency in the EC, the Foreign Ministers of France and Italy, a number of Ministers of Agriculture, and finally Commissioner Deniau visited Norway. The Norwegians took them to the Northern coast and flew them in small planes over the mountainous landscape in order to illustrate the conditions under which farmers had to work. ${ }^{60}$ This strategy certainly had an effect on German representatives. Following the visit of Ertl in July 1971, the German Ambassador to Norway saw it as a necessity that the Federal government started to work for a political solution that would meet Norway's special demands in the agricultural sector as far as possible. ${ }^{61}$ Even before the visit, the Auswärtiges Amt had argued that although Oslo's demands still were at odds with some Community principles, the size of Norwegian agriculture was so marginal and the political reasons for an accession so important that more flexibility

58. For a critical assessment by a researcher close to the party establishment, N. ØRVIK, The Norwegian Labor Party (NLP) and the 1972 Referendum, in: Idem. (ed.), Norway's No to Europe, International Studies: Occasional Papers, Pittsburgh, 1975, pp.19-41.

59. Six hear Oslo's demands for fishing, agriculture, in: Financial Times, 22.06.1971.

60. T. FRØYSNES, De norske jordbruksforhandlinger med EF. En forhandlingsteoretisk analyse, Master thesis, University of Oslo, 1973, pp.131-138; cf. H. ALLEN, op.cit., p.116.

61. PA AA, B 60, Bd.774, Oslo to AA, 16.7.71, Besuch BM Ertls, 05-07.07.1971. 
was necessary. ${ }^{62}$ The Norwegian maximum demands, however, still seemed difficult to achieve because Germany's partners took a much more principled stand. According to a key-official from the French Ministry of Commerce, the maintenance of deficiency payments was regarded as particularly problematic. Referring to the danger of setting precedence he said that France was "very much afraid of any kind of special solution" and therefore regarded the Norwegian claims as problematic. ${ }^{63}$ Foreign Minister Schumann recognized the special status of Norway's agriculture, but rejected the claim for permanent exceptions. In the end, he stated on a visit to Oslo, every country had to join the CAP. According to him, France had no particular interest in Norwegian agriculture or fisheries. The whole question was ,purely a matter of principle“". ${ }^{64}$ Of, course, France did have quite interest in the fisheries sector and tried to take care of them on the sidelines. However, French main interests were indeed a matter of principle, based on the maintenance of the existing CAP rules. Any precedence that would have given Britain or existing member states the possibility of opening this chapter in the near or distant future was of potential danger to Paris.

One of the most outspoken critics of the Norwegian negotiation strategy, however, was the Dutch Minister of Agriculture Pierre Lardinois. One had to bear in mind, he told Oslo's Ambassador, that sooner or later the Community would face lobbyists seeking to exploit the precedence established by the Norwegian deal. The worst thing that could happen would be a regionalisation of the CAP. ${ }^{65}$ Discussing the matter with German Foreign Minister Walter Scheel in October 1971, Lardinois stated that from a Dutch point of view, neither the fishery sector nor the agricultural sector should obtain unlimited derogations, at least not formally. In the Council the Dutch delegation boycotted an agreement on a compromise forwarded by the Commission that would have recognised Norway as a special case and included prolonged transition periods as well as financial support through Community funds. Two months later, when Lardinois paid Norway a visit, he remained unimpressed by the mountainous landscape that was meant to change his view on Norwegian special rights. Presumably the weather was too good and the scenery too idyllic to drive home the argument, as Norwegian Ambassador Søren Sommerfelt bitterly recalled. ${ }^{66}$ Desperate, Oslo even felt the need to send State Secretary Thorvald Stoltenberg to The Hague in order to remind the Dutch of their traditional support for enlargement. ${ }^{67}$ In the expert talks that started at the same time, the tone reportedly was pragmatic and solution oriented;

62. PA AA, B 60, Bd.774, Aufzeichnung IIIA5, Unterlagen für BM Ertl zum Norwegen Besuch.

63. UD 44.36/6.84-40, Paris to UD, 14.07.1971, EF. Samtale med Brunet.

64. UD 44.36/6.84-41, Notat, 1. H.pol.ktr., 29.07.1971, Samtaler med utenriksminister Schumann, 23.07.1971. Emphasis in original text.

65. UD 44.36/8-8, Haag to UD, 29.07.1971, EF-Norge. Fiske/Landbruk.

66. S.C. SOMMERFELT, Sendemann, Schibsted, Oslo, 1997, p.151; cf. UD 44.36/8-8, 1. Handelspol. kontor, 06.10.1971, Lardinois besøk i Norge, 16-19.09.1971.

67. UD 44.36/8-8, Den Haag to UD, 08.10.1971. 
at least concerning agriculture. ${ }^{68} \mathrm{~A}$ German diplomat attending a bilateral meeting with Norwegian officials reported that representatives of the ministries for Agriculture and Foreign Affairs now had been much more conciliatory than earlier, while attitudes in the ministry of Fisheries remained unchanged. ${ }^{69}$

With both sides displaying a certain political willingness to reach an agreement, negotiations went into their final phase after the summer break. In the agricultural sector, the new government had abandoned rather quickly the maximum position of the so-called "screening line" working for a permanent exemption from the CAP. Instead it had pursued what was known as the "compensation line", arguing that the difference between the Norwegian price level and the Community level had to be compensated for by the authorities. Similar to the position of the centre-right coalition the Labour government insisted on the maintenance of deficiency payments and direct subsidies as measure to compensate for the expected losses of farm incomes caused by the adjustment to Community price levels. In addition, Norway wanted to keep decision authority on the necessary adjustments under national control but to let the Community pay for the compensations through its European Agricultural Guarantee and Guidance Fund (EAGGF). These claims were not accepted entirely. But in early November, the Community finally presented its proposal for a compromise that some observers regarded as a fair deal. Under the condition that Norway would become part of the Community, the latter agreed to allow direct subsidies for certain products such as milk under the label of transport costs in order to guarantee supply for the entire country. The remaining negotiations concerned the length of the transition period for different groups of products. Here Norway obtained longer transitions than originally planned. Reactions in Norway varied from moderately positive to fiercely negative. The matter clearly was subject to interpretation as Norwegian Minister of Agriculture Thorstein Treholt exclaimed: "Call it what you want, I call it permanent exemptions". ${ }^{70}$

By December 1971 the parties were able to finalize the agreement. Following the meeting the Norwegian delegation said it would accept the Community's proposal for a special protocol attached to the accession treaty. By then, Trade Minister Per Kleppe judged the result as satisfactory, with the reservation that the result for the fisheries sector was still missing. ${ }^{71}$

The fisheries question, by contrast, was far from being resolved. The Norwegian government managed to reach a deal on the market organisation that met its demands.

68. T. FRØYSNES, op.cit. pp.117-121; The author is grateful to comments by Helmut von Verschuer, member of the Commission task force on enlargement and responsible for agricultural negotiations with Norway, who confirmed the pragmatic, collegial and friendly atmosphere among negotiators at the technical level.

69. PA AA, B 20, Bd.1835, III E 2 an Staatssekretär, 10.09.1971, Betr.: Integrationspolitische Gespräche mit norwegischen Regierungsvertretern.

70. Quoted in: T. KALDAHL, Jordbruksforhandlinger og landbrukspolitikk 1950-1980, Landbruksforlaget, Oslo, 1994, pp.337 f.

71. Arbeiderbevegelsens arkiv og bibliotek (AAB), DNA, Da, 489, Per Kleppe: Markedssaken, 30.12.1971. 
The difficult question was the coastal regime, where Norway insisted on the permanent maintenance of an exclusive zone of 12 miles. In the end, the fisheries question even had the potential to sabotage not only Norway's agreement but also the agreements reached with the other candidates. On 12 November, Britain, Ireland and Denmark had finally accepted a Community proposal that foresaw exclusive 12-mile zones for certain coastal areas. The transitional period would last until 1982 when the Community would have to revise the question again. Britain's chief negotiator Lord Geoffrey Rippon triumphantly called the deal a de facto permanent exemption and observers agreed that this was the end of CFP as it had been conceived in June 1970. ${ }^{72}$ Still, the Community had an interest in maintaining the impression that the acquis was left intact and Schumann in particular rejected the idea that permanent exemptions had been granted. ${ }^{73}$ But everybody was aware of the fact that Norway wanted to obtain more from the Community than the others had obtained. Despite heavy pressure from the British, they refused to join the 12 November deal. Instead, Norway was following the advice it had been given by Community representatives at the margins of the opening session on 22 September 1970: to wait for the conclusion of a special deal until the question of British membership was resolved. ${ }^{74}$ Norwegian experts had concluded from this advice that no agreement could be reached before the conclusion of the British negotiations and acted accordingly. ${ }^{75}$ Already in July Oslo had rejected a proposal by its co-applicants to join a multilateral session on the fisheries question. Britain had just reached a breakthrough in its negotiations following the summit meeting in June and had a strong interest in closing the remaining chapters as soon as possible. To Ireland and Denmark the fisheries question, although important, did not have the same significance it had for Norway. ${ }^{76}$ As Norway's Ambassador to the EC reminded his British colleague Kenneth Christofas, however, the Six had regarded his country as a special case since September 1970. Now Norway felt it had gained further understanding for its special conditions whereas the other applicants had not. Therefore, a coordinated approach was not in Norway's interest. ${ }^{77}$ Following the successful vote on the negotiation result in the House of Commons on 13 July 1971, the question of British entry seemed to be settled and the way for a special deal with Norway open. Indeed, the Community kept its word and judged Norwegian fisheries interests to be in a category apart. This did not mean, however, that the Six had given up their reluctance to grant permanent exclusive rights. On the

72. H. ALLEN, op.cit., p.122. Cf. M. RASMUSSEN, State power ..., op.cit., p.370.

73. B. DYNNA, Fiskerisektoren i de norske utvidelsesforhandlingene med EF (1970-72), Master thesis, University of Oslo, 1973, pp.167 f.

74. UD 44.36/6.84-35, Brussels to UD, 3.10.1971, Norge-CEE. Samtale med Boegner; UD 44.36/6.84-36, Bonn to UD, 20.10.1970, Utvidelsesforhandlingene. Sommerfelts besøk i Brüssel 16.10.1970; PA AA, B 20, Bd.1834, III E/IA2, 17.09.1970, Norwegen.

75. UD 44.36/6.84-35, Brussels to UD, 05.10.1970, Norge EEC.

76. M. RASMUSSEN, The Hesitant European - History of Denmark's Accession to the European Communities 1970-1973, in: Journal of European Integration History, 2(2005), pp.47-74; M. FITZGERALD, Ireland's relations with the EEC. From the treaties of Rome to Membership, in: Journal of European Integration History, 1(2001), pp.11-24.

77. UD 44.36/6.84-40, Brussels to UD, 26.06.1971, Norge-Storbritannia/Fiskerigrensen. See also UD 44.36/6.84-40, London to UD, 01.07.1971. 
one hand, the basic principles steering the Community attitude and the position of France in particular remained unchanged. On the other hand, the negotiations with the other applicants were not finally closed. Both British and Irish negotiators threatened to reconsider their agreement should the Norwegian obtain an all too favourable deal. ${ }^{78}$ Signals from Brussels suggested that the EC would go a long way in meeting Norwegian concerns but would stop short of granting the permanent maintenance of a 12-mile zone wanted by Oslo.

In an effort to act in accordance with Community principles without abandoning the claim for a 12-mile exclusive zone, the new government had decided to throw all its weight behind the so-called settlement solution. By asking foreign vessels to register properly in Norway, the right to equal access was meant to be circumvented. This attempt was outright rejected by the Community and in the end the government had to give in and opt for the once rejected division of the coastline. Acknowledging the heavy pressure on the Norwegian government by increasingly unhappy pressure groups, however, it was agreed that the exclusive zone would de facto include almost the entire coastline stretching from the Northern Cape to Egersund only a few miles away from the Southern most point. Still the question of a transitional period versus a permanent agreement had to be resolved.

The final weeks were marked by intensive negotiations accompanied by efforts at bilateral diplomacy. The central challenge was to find solutions that that did not break openly with the acquis and avoided to provoke a renegotiation of the deal reached with the other applicants.

\section{The compromises}

The agreement in the agricultural sector has been regarded as a fair compromise with give and take on both sides. The agreement mirrored the negotiations that had developed in a rather pragmatic way, with a good understanding among experts at the technical level. Not surprisingly, the agreement did not fulfil the maximum demands put forward by the interest organisations. These groups had not been entirely negative to the idea of EC membership, but their demands had been too high from the start and now they felt that the government had sacrificed their interests in order to secure an acceptable deal for the fisheries sector. The fisheries sector could not be entirely disappointed, given the concessions laid down in a special protocol. In fact, due to combined pressure from all four applicants, fisheries were the only sector of the entire enlargement negotiation where the Community had abandoned its negotiation pos-

78. PA AA, (B 20), Bd.1917, Aufzeichnung G1 III E, 13.01.1972, Fischereipolitik; hier: englische Reaktion auf die Norwegen-Formel. 
ition. ${ }^{79}$ The EC had agreed on a ten year transitional period and it had not excluded the possibility of revising the CFP after the end of the period. This makes the CFP a good example of the possible impact of an alliance of states with strong and well defined interests that mounts an "attack" on the acquis in an area where EC interests are contradictory or less well defined. ${ }^{80}$ In addition to its co-applicants, Norway had obtained a de facto exemption of its entire coastline.

Nevertheless, interest organisations were still not content. First of all the result was difficult to explain to the fishermen and to their supporters in the general public. The EC had not been able to issue a formal guarantee that would have assured Norway would maintain control over its extended exclusive zone beyond 1982. Political guarantees had been issued by some governments, assuring that the Community would never break its promise. This was not enough for those who feared from the outset that a small state like Norway would be run over by the big member states in every question of importance. And with the 30 June decision fresh in mind the sceptics had a powerful example to point to. The Minister for Fisheries, recruited from an interest organisation in order to secure their support, justified his resignation two days before the signature of the treaty exclusively with the lack of a legally binding guarantee. ${ }^{81}$ Norwegian diplomats regarded this move as a decisive blow to membership ambitions as it emphasised an enormous mistrust towards the Community itself..$^{82}$ Only a limited number of politicians and government officials were ready to accept the Community method.

This method had been explained rather bluntly by Pompidou in a conversation with Bratteli in early January 1972. Every member state, the French President lectured, wanted to safeguard its national interests and to obtain special rights - also France. But in a Community nothing was as important as the maintenance of principles. Depicting himself as an almost impartial observer, he said that in his view the Community had gone very far into Norway's direction whereas Norway had barely moved. Now everybody had to sit down in a marathon meeting and at the end of the night a compromise would emerge that everybody had to accept. ${ }^{83}$

This prediction proved to be true, at least to some extent. The written result of this compromise, however, the treaty of accession, was packed in such complicated phrases that it was impossible to explain its presumed advantages to a broader public. Following the signature of the treaty on 22 January, the Neue Zürcher Zeitung viewed the opposition to Norwegian membership as weakened. ${ }^{84}$ In fact, the contrary was

79. E. WELLENSTEIN, L'élargissement de la Communauté, vu de Bruxelles, in: ASSOCIATION GEORGES POMPIDOU (ed.), Georges Pompidou et l'Europe, Ed. Complexe, Paris, 1995, pp. 235 f.; J.M. BOEGNER, Le Marché Commun de six à neuf, Armand Colin, Paris 1976²., pp.188f.

80. M. RASMUSSEN, State power ..., op.cit., pp.374.

81. His letter is printed in J. NYHAMAR, Nye utfordringer. Arbeiderbevegelsens historie i Norge, vol. 6, 1965-1990, Tiden Norsk Forlag, Oslo 1990, p.162.

82. PA AA, B 20, Bd.1917, Staatssekretär von Braun an Herrn D III, 19.01.1972, EWG-Norwegen.

83. UD 44.36/6.84-45, Brussels to UD, 07.01.1972, Samtale med president Pompidou.

84. Norwegens Einigung mit dem Gemeinsamen Markt. Geschwächte Stellung der Beitrittsgegner, in: Neue Zürcher Zeitung, 19.01.1972. 
true. An unholy but forceful alliance of farmers, urban intellectuals, and Christian fundamentalists joined in a people's movement against membership that had broad appeal in the population. Resistance was not limited to but absolutely strongest at the periphery, in areas dependent on agriculture and fishery. Their powerful interest organisations had both financial clout and organisational mobilizing capacity. Their resistance, partly based on fear of change, partly on utilitarian reasons, had a strong influence on their members and a great appeal to the population in general. In a population of four million almost everybody had relatives with connections to a rural Community. ${ }^{85}$

\section{Conclusion}

This article has set out to revisit the question why Norway had engaged in membership negotiations with the EC in 1970 despite its difficulties with the concept of integration and why the Community had opened negotiations with a country that not only wanted to be excluded from the CAP and the CFP but also had severe reservations against the political goals inherent in the Rome Treaties. It was argued that an analysis of the negotiations themselves was needed to judge whether positions on both sides were too principled to leave room for an acceptable compromise.

It can be argued that the negotiations themselves ended successfully. Norway had to be satisfied with its status as a special case and even though no permanent exemption was achieved, it had obtained far reaching derogations from the CAP and the CFP. The Norwegian government was able to look back on difficult negotiations where both the Six and the other candidates accepted a deal that to a large degree was the result of Norwegian stubbornness. But also the EC was able to regard the agreement as a success, because the CAP principles and thus the acquis were left more or less intact. More importantly, enlargement that had been a cause for tension throughout the 1960s was finally brought on its way and could be expected to infuse the Community with new dynamism.

However, taking the rejection of the treaty of adhesion in the popular referendum of 25 September 1972 into account, it can be equally argued that the negotiations were unsuccessful, first of all from a Norwegian perspective, but also both from a Community perspective. The referendum proved what had been suspected by many already during the negotiation's final days, namely that negotiations had led to a compromise that was not acceptable to interest groups. But the Bratteli government had negotiated for a successful accession and refused to accept a looser accession agreement as a fall back position. It resigned immediately after the referendum, leav-

85. N.P. GLEDITSCH et al., The Common Market issue in Norway: Conflict between center and periphery, in: Journal of Peace Research, 12(1975), pp.37-53; C. SCHYMIK, Europäische AntiFöderalisten. Volksbewegungen gegen die Europäische Union in Skandinavien, EKF Wissenschaft, Leipzig, 2006. 
ing it to the mainly eurosceptical parties to negotiate a free trade agreement with the EC. Nor could the Six be entirely satisfied with the final outcome of the Norwegian case. There were certainly those who were not too unhappy seeing a potentially difficult partner opting out. ${ }^{86}$ But the general reaction was one of annoyance, disappointment and - to some degree - self-criticism. First of all there was annoyance over the fact that the Six had to revise original CFP and that even this move had not helped convince all applicants to join. Some conference diplomats even wondered whether Britain, Denmark and Ireland would have obtained such far reaching concessions, had it not been for Norway's tough negotiating style.

More generally, the Norwegian non-ratification left a stain on the first round of enlargement. This failure was even more deplorable as Community representatives had to acknowledge that Norway's "no" - domestic reasons apart - was also a criticism of the Community method and reflected growing dissatisfaction with the integration process. Following the Norwegian rejection of the treaty, some Community representatives expressed self-criticism, deploring the way in which the EC had behaved during the negotiations. Le Monde called the decision a "Warning to all Europeans". ${ }^{87}$ Like Sicco Mansholt, however, most of them pointed to the Community's image rather than to the details and the substance of the negotiation. ${ }^{88}$

While the "classical Community Method", i.e. the insistence on the unconditional acceptance of the acquis by new members, was regarded as complicated and sometimes ineffective, it was seen as the best way to defend both Communitarian and member state interests. ${ }^{89}$ Nevertheless, the widespread impression of failure, both on the Norwegian and on the Community side, leads to the question whether the outcome was predetermined and if negotiations could have turned out differently. Uwe Kitzinger who in 1973 provided one of the first detailed accounts of the first round of enlargement negotiations, has analysed them as ,,a self-contained system and a procedure for settling minor issues of a transitional character". Citing conference diplomats he maintains that most of the questions on the table were of "gigantic irrelevance" and could have been agreed upon over a cup of tea and a brandy. ${ }^{90}$ As Norway's case has shown, this did not mean that negotiations had to lead to a successful ratification. Indeed, as Norwegian historians have argued, in 1962, 1967 and 1970-72 it was hard to see how any agreement that complied with the acquis could have satisfied Norwegian interests. There was, however, nothing predetermined in the outcome of the negotiations. Both public and internal records show that the out-

86. For examples see: Norwegens Nein - von vielen Erwünscht, in: Der Spiegel, 02.10.1972.

87. Un avertissement, in: Le Monde, 27.09.1972. See also Warnung aus dem Norden, in: Frankfurter Rundschau, 27.09.1972.

88. Le 'non' de la Norvège, in: RTL-interview with Sicco Mansholt and Jean. Monnet, http:// www.ena.lu/non_norvege_rtl_26_septembre_1972-2-9070.

89. C. PRESTON, Obstacles to EU Enlargement: The Classical Community Method and the Prospects for a Wider Europe, in: Journal of Common Market Studies, 3(September 1995), pp.451-463. See also M. RASMUSSEN, State power ..., op.cit., pp.361 f.

90. U. KITZINGER, Diplomacy and Persuasion. How Britain Joined the Common Market, Thames and Hudson, London, 1973, pp.75 and 77. 
come of negotiations as well as the result of the referendum campaign was undetermined until the end. Enlargement negotiations were already in the early 1970s a complex multilevel game, where certain norms and rules were applied and followed, but where a multitude of different factors and actors defined the outcome. ${ }^{91}$ Officially, Norway and the Community met 27 times during the 19 month long negotiations, ten times at ministerial level and 17 times on deputy level. In addition there were countless informal consultations and meetings among experts. Depending on the subject and on the phase, the expert level was more important than the political level whereas in other phases political initiatives were decisive and able to push the process towards a compromise. Also, bilateral contacts between applicants and member states could have a decisive impact upon the negotiations. Such contacts were allowed and even encouraged as long as they did not thwart the EC's common negotiating position. Together, these contacts had the side-effect of making the negotiations more integrative and contributed to further understanding among negotiators. This explains to some degree why it was possible to find a compromise even to Norway's intricate problems in the primary sector.

However, although negotiators constantly took domestic factors into account and even used domestic pressure as a negotiation tool, they apparently operated too remotely from the people and in the Norwegian case the electorate had the final word on the result. Until the failure of the last marathon sessions in January 1972 and the subsequent resignation of the Norwegian Minister of Fisheries, there was still some optimism among negotiators that the government would be able to defend the result at home. Against the advice of some of his closest advisers and despite growing opposition, Bratteli signed the accession treaty and started the ratification process. During the eight months of hard campaigning the Labour party mobilised its troops and the Yes-campaign gained some ground that was lost earlier. At the same time, several incidences in Norway and in the EC made things more difficult for the proponents of entry.

At this point a counterfactual question might be introduced: ${ }^{92}$ was it right of the Community to stay firm on its principles? What would have been the consequences of granting Norway the far reaching exemptions it had asked for? A number of factors were responsible for the "no" but the negotiations' result and the way it had been achieved clearly were among them. Norwegians were deeply disappointed at not being able to make their voices heard in a sector where their country had to be regarded as a central player. Farmers, fishermen and all those sceptical of European integration got their view confirmed that a small state like Norway would not be in a position to defend even its most vital interests.

91. A. UNDERDAL, Multinational Negotiation Parties - The Case of the European Community, in: Cooperation and Conflict, 8(1973), pp.173-182.

92. On the pros and cons of introducing counterfactual questions into a historical analysis, see M. BUNZL, Counterfactual History: A User's Guide, in: The American Historical Review June 2004, http://www.historycooperative.org/journals/ahr/109.3/bunzl.html (28 Aug. 2010). 
Could the Community have acted differently? Was not there some more room to stretch the principles a bit further, allowing the Norwegian government to "sell" the result as representing a guarantee for safeguarding national interests in the agrarian sector? Could not and should not the Community have accepted from the start that a CFP was impossible to conceive without the participation of future members whose inclusion would radically change the size and character of the regime? Would a special regime for Norway really have jeopardized the conclusion of the enlargement process and undermined the CAP?

It is certainly stimulating to take counterfactual questions as a starting point for a discussion on the adequacy of the now "classical Community method", centred on the unconditional acceptance of the acquis. In a historical analysis, however, the wider political context in which the negotiations took place cannot be ignored. The 1970-72 process was marked, first of all, by the French fear of an all out attack on the CAP and by its partner's politically motivated consent not to provoke a crisis over this question. In an atmosphere still under the impression of the crises of the sixties, and influenced by Germany's preoccupation with support for its Ostpolitik, it is hard to imagine the Community embarking on a major reform project that most certainly would have endangered its internal cohesion. The unity of the Common Market was in everybody's interest and the consent on the centrality of the acquis was the kit that held the Community together. Instead of using the applicant's challenge to CAP and $\mathrm{CFP}$ as an incitement to reform an arguably ill-devised and increasingly unpopular policy, the acceptance of the acquis became the key concept of EC enlargement. To the present day, this principle has made every further enlargement a painfully long and ever more complicated process. On the one hand it protects the European Community (and today the EU) against disintegrating influences from future partners that are unable or unwilling to share the full obligations of full membership. At the same time, however, the insistence on the acquis seems to reduce the EC/EU's ability to absorb initiatives for reform. 


\section{Taking Farmers off Welfare. The EEC Commission's Memorandum “Agriculture 1980" of 1968}

\section{Katja SEIDEL}

Agriculture is in crisis, again. During his visit to the Paris Salon de l'Agriculture on 6 March 2010 French President Nicolas Sarkozy acknowledged that the sector suffered from a climate of crisis and fear and that young people in particular must seriously doubt whether they had a future in farming. He condemned the path the Common Agricultural Policy (CAP) has taken since the early 1990s, namely to "exchange prices against subventions". Farmers, according to him, were entrepreneurs who needed to gain their incomes from prices and not subventions. At the same time, he announced that, should the agricultural budget of the European Union (EU) be slashed further, France would insist on Community preference and price policy to compensate for the cuts, otherwise "ce n'est plus l'Europe". ${ }^{1}$

Nearly fifty years after setting up the CAP and eighteen years after the 1992 MacSharry reforms, agricultural policy and the economic and social situation of farmers still draw the political attention in Europe. The fact that in the year 2010 the French President advocates a strengthening of Community preference and a return to price policy that had caused the EU budget nearly to collapse in the 1980s, invites an analysis of the first attempt of reforming the CAP in 1968. Here, too, the point of departure was "a feeling of despair" that had "gripped many farmers, who see no future in their work". ${ }^{2}$ In the late 1960s, the flaws of the CAP, a "welfare policy" the European Economic Community (EEC) had established to help the agricultural sector survive the economic and social transitions post-war Europe was undergoing, were blatant. ${ }^{3}$ The situation was characterised by increasing costs of market support and price policy - the two pillars of the CAP - and the inability of many farmers in the six member states to generate a sufficient income in spite of the costly support mechanisms. At the same time the high agricultural prices started to lead to costly structural surpluses for some commodities, in particular dairy products, wheat and sugar.

1. Information and quotations from http://www.france-info.com/france-politique-2010-03-06-sarkozyannonce-des-mesures-de-soutien-a-1-agriculture-413962-9-10.html, accessed 06.03.2010.

I would like to thank the German Historical Institute Paris for generous funding of this research project. I am grateful to Fernando Guirao and an anonymous referee for their very helpful comments on an earlier version of the article and to the participants of the workshop at Maastricht University in April 2010.

2. $\$ 33$ of the "Memorandum on the Reform of Agriculture in the European Economic Community and Annexes", COM(68)1000 final, Parts A and B, 18.12.1968; Bulletin of the European Communities, Supplement No.1/69, pp.9-46. This memorandum, which was submitted by the Commission to the Council on 21 December 1968, is henceforth referred to as the Mansholt Plan (MP).

3. On the welfare policy paradigm see A.C.L. KNUDSEN, Farmers on Welfare. The Making of Europe's Common Agricultural Policy, Cornell University Press, Ithaca, 2009. On the costs of the CAP see the contribution of Mark Spoerer in this volume. 